\title{
Occurrence of Natural Enemies of Maize Stem Borer Chilo partellus (Swinhoe) in Kharif Maize Ecosystem
}

\author{
Pravasini Behera* and Bijoy Kumar Mishra \\ ${ }^{1}$ Department of Entomology, OUAT, Bhubaneswar, Odisha, India \\ ${ }^{2}$ CA \& Former Head and Professor, Dept. of Entomology, \\ OUAT, Bhubaneswar, Odisha, India \\ *Corresponding author
}

\section{A B S T R A C T}

Field experiments were carried out at Maize field of AICRP on Maize, Central farm, OUAT, Bhubaneswar, Odisha during Kharif 2014 and Kharif

Keywords

Maize, Chilo partellus, Natural enemies and

Standard

Meteorological

Week

\section{Article Info}

Accepted:

15 February 2020

Available Online:

10 March 2020
2015 to document the "Occurrence of natural enemies of maize stem borer Chilo partellus (Swinhoe) in Kharif maize ecosystem". The average seasonal coccinellid population in Kharif 2014 and Kharif 2015 was in between 1.10 to 1.20 per plant respectively from $30^{\text {th }}$ SMW (19 DAS) to $40^{\text {th }}$ SMW(89DAS) .Number of eggs/ plant laid by the green lacewings, Chrysoperla carnea recorded 0.07 to 0.43 / plant and 0.04 to $0.47 /$ plant in the same time period. Mixed population of two predominant spider population over two growing seasons reached maximum (1.56/ plant) and $(1.55 /$ plant $)$ at $39^{\text {th }}$ SMW in maize ecosystem in both the seasons. Syrphid maggots reached the peak (1.26. and 0.80) / plant in maize at $40^{\text {th }} \mathrm{SMW}$ in these years ranged from 0.68 to $1.75 /$ plant. Pentatomid bug, Eocanthecona. furcellata was very negligible on maize crop. Reduviid bugs appeared from $31^{\text {st }}$ to $40^{\text {th }} \mathrm{SMW}$ however in growing seasons the population varied from 0.03 to $0.26 /$ plant.

\section{Introduction}

Maize (Zea mays L.) is the most important cereal crop after wheat and rice, grown virtually in every suitable agricultural region of the world. It belongs to the grasses family Poaceae (Gramineae). Maize is a fully domesticated plant which has lived with man and evolved since ancient times. It has been referred as the "Queen of cereals" due its highest yield potential among all the cereals (Ali et al., 2014). Maize is attacked by over 250 species of insect and pests ${ }^{[3] .}$ Of those four species of tissue borers viz., maize stem borer or spotted stem borer (Chilo partellus Swinhoe), pink stem borer (Sesamia 
inference), shoot fly (Atherigona soccata) and Asiatic corn borer (Ostrinia furnacalis Guenee) are regular and serious pests of maize. Among these, maize stem borer, $C$. partellus, is the principal pest in all maize growing countries. The yield losses caused by this ranges from 26.7 to $80.4 \%$ in different agro-climatic zones of India (Chatterji et al., 1969). Further, Singh and Sajjan (1982) reported that the tune of losses caused by $C$. partellus in maize ranged from 57.70 to $79.40 \%$ in Punjab. Natural enemies plays important role in suppression of this target insects and also an important component of integrated pest management practice.

\section{Materials and Methods}

A field trial on Occurrence of Natural enemies of Maize stem borer Chilo partellus (Swinhoe) in Kharif maize ecosystem was conducted at the Central research farm, Odisha University of Agriculture and Technology during Kharif 2014 and Kharif 2015. The experiment comprised of fifteen numbers of popular cultivars of maize viz. MRM 3777, DMH 7705, DKC9117, VIVEK HYBRID-9, VIVEK QPM-9, NMH-1247, NK-30, BIO 9681, BIO 9637, CORN S 6217, ASMH 177, HM-4, HQPM-1, HQPM -5 and DKC 8101. The raising of maize crop was done by following AICRP on Maize recommendations (Annual report 2014). The experiment was laid out in Randomized Block Design (RBD)(Gomez and Gomez 1984) with fifteen treatments and replicated thrice with spacing of $60 \mathrm{~cm} \times 25 \mathrm{~cm}$ except the application of insecticides.

Sixteen plants were maintained in each row. The predatory population viz., lady bird beetle (grubs and adults), green lace wings (eggs and grubs), syrphid grubs, predatory pentatomid bug and spider populations were recorded on whole plant basis at weekly intervals from the 25 randomly selected plants from 19 days after germination DAS onwards. Observations on insect pests and their natural enemies were taken from each experimental plot leaving the boarder rows

\section{Results and Discussion}

\section{Lady bird beetle (Coccinellids)}

Predominant lady bird beetle species (Table 1) were recorded from maize agro ecosystem. These major predatory coccinellid species were noticed in early vegetative stage of crop growth i.e., from $30^{\text {th }}$ SMW (19 DAS) to $40^{\text {th }}$ SMW with varying degree of population. The mixed population of both grubs and adults reached at their peak recording 1.75/ plant followed by 1.53 / plant which were observed during $39^{\text {th }}$ SMW and $33^{\text {rd }}$ SMW respectively in maize in the growing season Kharif 2014 and Kharif 2015. The grub and adult coccinellid population were at their plateau (1.86/ plant) during $39^{\text {th }}$ SMW and (1.51/ plant) during $40^{\text {th }}$ SMW in the year 2014. However, the average seasonal coccinellid population in Kharif 2014 and Kharif 2015 years was in between 1.10 to 1.20 per plant respectively. In general, there was no significant difference between preferences of lady bird beetle on maize crop.

\section{Green lacewings Chrysoperla carnea Stephens}

Observations recorded on the number of eggs/ plant laid by the green lacewings, C.carnea showed that (Table 1) there was no significant difference between preference of egg laying in maize during both the growing seasons. It was evident from the observations that majority egg laying by $C$. carnea recorded during $30^{\text {th }}$ and $39^{\text {th }} \mathrm{SMW}$ of Kharif 2014and again during $38^{\text {th }}$ to $40^{\text {th }}$ SMW of Kharif 2015 in maize ecosystem . However, the seasonal weekly average egg numbers over the years varied from 0.07 to 0.43 / plant 
and 0.04 to $0.47 /$ plant in maize in Kharif 2014 and Kharif 2015 respectively

\section{Syrphid, Ischiodon scutellaris (Fabricius)}

From the Table 2 it was revealed that the predatory dipteran syrphid fly, I. scutellaris appeared in the maize agro ecosystem during $30^{\text {th }}$ SMW of the year 2014 and 2015 respectively.

The syrphid maggots fed on the larvae without any significant difference in their population abundance in maize. The combined weekly mean population of syrphid maggots reached the peak 1.26. and 0.81/ plant in maize at $39^{\text {th }}$ SMW in the years kharif 2014 and Kharif 2015 respectively. The predator remained active up to $40^{\text {th }} \mathrm{SMW}$ i.e., 1st week of October. The mean seasonal population of syrphid maggots ranged from 0.16 to $1.01 /$ plant in maize over the two years.

\section{Spiders}

Mixed population of two predominant spider species (Table 2 ) were prevalent in maize agro ecosystem during the growing seasons of Kharif 2014 and Kharif 2015. They were the most dominant predators throughout the cropping season.

The observations recorded on mixed population/plant revealed that there was no significant difference between abundance of spiders in maize hybrids. The activities of spiders commenced from $30^{\text {th }}$ SMW and it was continued till $40^{\text {th }}$ SMW in both the growing seasons.

The weekly mean population of spiders over two growing seasons reached maximum (1.56/ plant) at $39^{\text {th }}$ and ( $1.55 /$ plant $)$ at $39^{\text {th }}$ in maize ecosystem in both the seasons respectively.
Predatory Pentatomid bug, Eocanthecona furcellata Wolff.

The population of the predatory pentatomid bug, E. furcellata was very negligible on maizecrop (Table 3). However, they appeared on both the crops in both the years with a little bit variation in their population.

\section{Reduviid bugs}

The reduviid bugs appeared on maize only (Table 3 ). The population observed at $31^{\text {st }}$ to $40^{\text {th }}$ SMW in the year Kharif 2014 and Kharif 2015 respectively. The population was high i.e., 0.25 and $0.27 /$ plant in the year Kharif2014 and Kharif 2015 respectively. However, the seasonal weekly mean parasitoid population over the two growing seasons varied from 0.03 to 0.26 / plant.

The mixed population of both grubs and adults of coccinellids reached at their peak recording $1.75 /$ plant followed by $1.53 /$ plant which were observed during $39^{\text {th }}$ SMW and $33^{\text {rd }}$ SMW in respectively in maize in the growing season kharif 2014 and Kharif 2015. The grub and adult coccinellid population were at their plateau $(1.86 /$ plant $)$ during $39^{\text {th }}$ SMW and (1.51/ plant) during $40^{\text {th }}$ SMW in the year 2014. However, the average seasonal coccinellid population in Kharif 2014 and Kharif 2015 years was in between 1.10 to 1.20 per plant respectively. Aziz et al., (2017) reported among the predators, the major insect groups included Coccinellids, Chrysopa spp., Pheidole spp., Reduvid spp., Mantisreligiosa, Scolothripsand Euborellia spp., Coccinella septumpunctata was having high relative abundance followed by Chrysopa spp. Rana (2004) conducted a three year experiment on rape seed and mustard crop to evaluate the response of $C$. septempunctata and $M$. sexmaculatus against Lipaphis erysimi. 
Table.1 Seasonal incidence of lady bird beetle and Chrysoperla population under maize in unprotected conditions at Maize research farm, OUAT, Bhubaneswar during

kharif 2014 and kharif 2015

\begin{tabular}{|c|c|c|c|c|c|c|c|c|}
\hline \multirow[t]{2}{*}{$\begin{array}{c}\text { SM } \\
\text { W }\end{array}$} & \multirow[t]{2}{*}{ Period } & \multirow[t]{2}{*}{$\begin{array}{c}\text { DA } \\
\text { S }\end{array}$} & \multicolumn{3}{|c|}{$\begin{array}{c}\text { Ladybird beetle grub and } \\
\text { adult } \\
\text { (Nos./plant) }\end{array}$} & \multicolumn{3}{|c|}{$\begin{array}{l}\text { Chrysoperla sp. eggs } \\
\text { (Nos./plant) }\end{array}$} \\
\hline & & & $\begin{array}{c}\text { Kharif } \\
2014\end{array}$ & $\begin{array}{c}\text { Kharif } \\
2015\end{array}$ & $\begin{array}{c}\text { Pooled } \\
\text { mean }\end{array}$ & $\begin{array}{c}\text { Kharif } \\
2014\end{array}$ & $\begin{array}{c}\text { Kharif } \\
2015\end{array}$ & $\begin{array}{c}\text { Pooled } \\
\text { mean }\end{array}$ \\
\hline 30 & 23th-29 $9^{\text {th }}$ July & 19 & 1.13 & 1.16 & 1.15 & 0.25 & 0.04 & 0.14 \\
\hline 31 & $30^{\text {th }}$ July $-5^{\text {th }}$ Aug & 26 & 0.80 & 0.55 & 0.68 & 0.08 & 0.15 & 0.11 \\
\hline 32 & $6^{\text {th }}-12^{\text {th }}$ August & 33 & 1.28 & 1.33 & 1.30 & 0.09 & 0.14 & 0.12 \\
\hline 33 & $13^{\text {th }}-19^{\text {th }}$ August & 40 & 1.40 & 1.65 & 1.53 & 0.07 & 0.16 & 0.11 \\
\hline 34 & $20^{\text {th }}-26^{\text {th }}$ August & 47 & 1.03 & 0.61 & 0.82 & 0.11 & 0.13 & 0.12 \\
\hline 35 & $\begin{array}{l}27^{\text {th }}-02^{\text {nd }} \\
\text { September }\end{array}$ & 54 & 0.85 & 0.78 & 0.81 & 0.08 & 0.15 & 0.12 \\
\hline 36 & $\begin{array}{l}03^{\text {rd }}-09^{\text {th }} \\
\text { September }\end{array}$ & 61 & 0.72 & 0.89 & 0.81 & 0.10 & 0.16 & 0.13 \\
\hline 37 & $\begin{array}{l}10^{\text {th }}-16^{\text {th }} \\
\text { September }\end{array}$ & 68 & 1.45 & 0.73 & 1.09 & 0.16 & 0.18 & 0.17 \\
\hline 38 & $\begin{array}{l}17^{\text {th }}-23^{\text {rd }} \\
\text { September }\end{array}$ & 75 & 1.19 & 1.41 & 1.30 & 0.08 & 0.19 & 0.14 \\
\hline 39 & $\begin{array}{l}24^{\text {th }}-30^{\text {th }} \\
\text { September }\end{array}$ & 82 & 1.86 & 1.64 & 1.75 & 0.43 & 0.47 & 0.45 \\
\hline \multirow[t]{4}{*}{40} & $01^{\text {st }}-07^{\text {th }}$ October & 89 & 1.51 & 1.39 & 1.45 & 0.12 & 0.24 & 0.18 \\
\hline & Range & & $\begin{array}{c}0.72- \\
1.86\end{array}$ & $0.55-1.64$ & $\begin{array}{c}0.68- \\
1.75\end{array}$ & $\begin{array}{l}0.07- \\
0.43\end{array}$ & $0.04-0.47$ & $\begin{array}{c}0.12- \\
0.45\end{array}$ \\
\hline & Mean \pm SD & & $\begin{array}{l}1.20 \pm 0.3 \\
5\end{array}$ & $\begin{array}{c}1.10 \pm 0.4 \\
2\end{array}$ & $\begin{array}{c}1.15 \pm 0.3 \\
5\end{array}$ & $\begin{array}{c}0.14 \pm 0.1 \\
1\end{array}$ & $\begin{array}{c}0.18 \pm 0.1 \\
0\end{array}$ & $\begin{array}{c}0.16 \pm 0.0 \\
9\end{array}$ \\
\hline & & & NS & NS & NS & NS & NS & NS \\
\hline
\end{tabular}


Table.2 Seasonal incidence of Syrphid fly and Spiders population in maize under unprotected conditions at Maize research farm, OUAT, Bhubaneswar during Kharif 2014 and Kharif 2015

\begin{tabular}{|c|c|c|c|c|c|c|c|c|}
\hline \multirow[t]{2}{*}{ SMW } & \multirow[t]{2}{*}{ Period } & \multirow{2}{*}{$\begin{array}{c}\text { DA } \\
\mathbf{S}\end{array}$} & \multicolumn{3}{|c|}{ Syrphid fly(Nos./plant) } & \multicolumn{3}{|c|}{ Spiders (Nos./plant) } \\
\hline & & & $\begin{array}{c}\text { Kharif } \\
2014\end{array}$ & $\begin{array}{c}\text { Kharif } \\
2015\end{array}$ & $\begin{array}{l}\text { Pooled } \\
\text { mean }\end{array}$ & $\begin{array}{c}\text { Kharif } \\
2014\end{array}$ & $\begin{array}{c}\text { Kharif } \\
2015\end{array}$ & $\begin{array}{l}\text { Pooled } \\
\text { mean }\end{array}$ \\
\hline 30 & 23th-29 ${ }^{\text {th }}$ July & 19 & 0.83 & 0.24 & 0.53 & 1.37 & 0.33 & 0.85 \\
\hline 31 & $30^{\text {th }}$ July- $-5^{\text {th }}$ Aug & 26 & 0.18 & 0.15 & 0.16 & 0.26 & 0.61 & 0.43 \\
\hline 32 & $6^{\text {th }}-12^{\text {th }}$ August & 33 & 1.20 & 0.29 & 0.74 & 1.09 & 0.73 & 0.91 \\
\hline 33 & $13^{\text {th }}-19^{\text {th }}$ August & 40 & 0.73 & 0.27 & 0.50 & 1.23 & 1.03 & 1.13 \\
\hline 34 & $20^{\text {th }}-26^{\text {th }}$ August & 47 & 0.78 & 0.19 & 0.49 & 0.86 & 0.35 & 0.61 \\
\hline 35 & $27^{\text {th }}-02^{\text {nd }}$ September & 54 & 0.12 & 0.75 & 0.44 & 0.13 & 0.77 & 0.45 \\
\hline 36 & $03^{\text {rd }}-09^{\text {th }}$ September & 61 & 0.36 & 0.43 & 0.40 & 0.41 & 0.72 & 0.57 \\
\hline 37 & $10^{\text {th }}-16^{\text {th }}$ September & 68 & 0.67 & 0.34 & 0.51 & 0.99 & 0.81 & 0.90 \\
\hline 38 & $17^{\text {th }}-23^{\text {rd }}$ September & 75 & 0.50 & 0.35 & 0.43 & 0.31 & 1.18 & 0.74 \\
\hline 39 & $24^{\text {th }}-30^{\text {th }}$ September & 82 & 1.26 & 0.81 & 1.04 & 1.56 & 1.55 & 1.55 \\
\hline \multirow[t]{4}{*}{40} & $01^{\text {st }}-07^{\text {th }}$ October & 89 & 0.83 & 0.34 & 0.58 & 0.99 & 0.90 & 0.94 \\
\hline & Range & & $0.12-1.26$ & $0.15-0.81$ & $0.16-1.04$ & $0.13-1.56$ & $0.33-1.55$ & $0.43-1.55$ \\
\hline & Mean \pm SD & & $0.68 \pm 0.39$ & $0.38 \pm 0.22$ & $0.53 \pm 0.22$ & $0.84 \pm 0.49$ & $0.81 \pm 0.35$ & $0.82 \pm 0.32$ \\
\hline & & & NS & NS & NS & NS & $\mathrm{S}$ & NS \\
\hline
\end{tabular}


Table.3 Seasonal incidence of predatory pentatomid bugs and Reduviid bugs population in maize under unprotected condition at maize research farm, during kharif 2014 and kharif 2015

\begin{tabular}{|c|c|c|c|c|c|c|c|c|}
\hline \multirow[t]{2}{*}{ SMW } & \multirow[t]{2}{*}{ Period } & \multirow[t]{2}{*}{ DAS } & \multicolumn{3}{|c|}{$\begin{array}{l}\text { Predatory Pentatomid bugs } \\
\text { (Nos./plant) }\end{array}$} & \multicolumn{3}{|c|}{$\begin{array}{l}\text { Reduviid bugs } \\
\text { (Nos./plant) }\end{array}$} \\
\hline & & & $\begin{array}{c}\text { Kharif } \\
2014\end{array}$ & $\begin{array}{c}\text { Kharif } \\
2015\end{array}$ & $\begin{array}{c}\text { Pooled } \\
\text { mean }\end{array}$ & $\begin{array}{c}\text { Kharif } \\
2014\end{array}$ & $\begin{array}{c}\text { Kharif } \\
2015\end{array}$ & $\begin{array}{c}\text { Pooled } \\
\text { mean }\end{array}$ \\
\hline 30 & 23 th-29 $9^{\text {th }}$ July & 19 & 0.16 & 0.11 & 0.14 & 0.05 & 0.00 & 0.00 \\
\hline 31 & $30^{\text {th }}$ July- $5^{\text {th }}$ Aug & 26 & 0.19 & 0.05 & 0.12 & 0.18 & 0.13 & 0.15 \\
\hline 32 & $6^{\text {th }}-12^{\text {th }}$ August & 33 & 0.08 & 0.15 & 0.11 & 0.07 & 0.00 & 0.03 \\
\hline 33 & $13^{\text {th }}-19^{\text {th }}$ August & 40 & 0.18 & 0.19 & 0.19 & 0.15 & 0.17 & 0.16 \\
\hline 34 & $20^{\text {th }}-26^{\text {th }}$ August & 47 & 0.29 & 0.15 & 0.22 & 0.22 & 0.27 & 0.25 \\
\hline 35 & $\begin{array}{l}27^{\text {th }}-02^{\text {nd }} \\
\text { September }\end{array}$ & 54 & 0.23 & 0.04 & 0.13 & 0.00 & 0.16 & 0.08 \\
\hline 36 & $\begin{array}{l}03^{\text {rd }}-09^{\text {th }} \\
\text { September }\end{array}$ & 61 & 0.11 & 0.20 & 0.16 & 0.17 & 0.08 & 0.13 \\
\hline 37 & $\begin{array}{l}10^{\text {th }}-16^{\text {th }} \\
\text { September }\end{array}$ & 68 & 0.15 & 0.03 & 0.09 & 0.25 & 0.26 & 0.26 \\
\hline 38 & $\begin{array}{l}17^{\text {th }}-23^{\text {rd }} \\
\text { September }\end{array}$ & 75 & 0.10 & 0.13 & 0.11 & 0.06 & 0.00 & 0.03 \\
\hline 39 & $\begin{array}{l}24^{\text {th }}-30^{\text {th }} \\
\text { September }\end{array}$ & 82 & 0.31 & 0.17 & 0.24 & 0.16 & 0.13 & 0.14 \\
\hline \multirow[t]{4}{*}{40} & $01^{\text {st }}-07^{\text {th }}$ October & 89 & 0.15 & 0.07 & 0.11 & 0.21 & 0.15 & 0.18 \\
\hline & Range & & $0.10-0.31$ & $0.04-0.19$ & $0.11-0.24$ & $0.00-0.25$ & $0.00-0.26$ & $0.00-0.26$ \\
\hline & Mean \pm SD & & $0.18 \pm 0.08$ & $0.12 \pm 0.07$ & $0.15 \pm 0.04$ & $0.14 \pm 0.08$ & $0.12 \pm 0.09$ & $0.13 \pm 0.08$ \\
\hline & & & NS & NS & NS & NS & NS & NS \\
\hline
\end{tabular}


Fig.1 Graphical representation of population of natural enemies of maize stem borer from $30^{\text {th }}$ SMW to $39^{\text {th }}$ SMW during kharif -2014 and kharif -2015

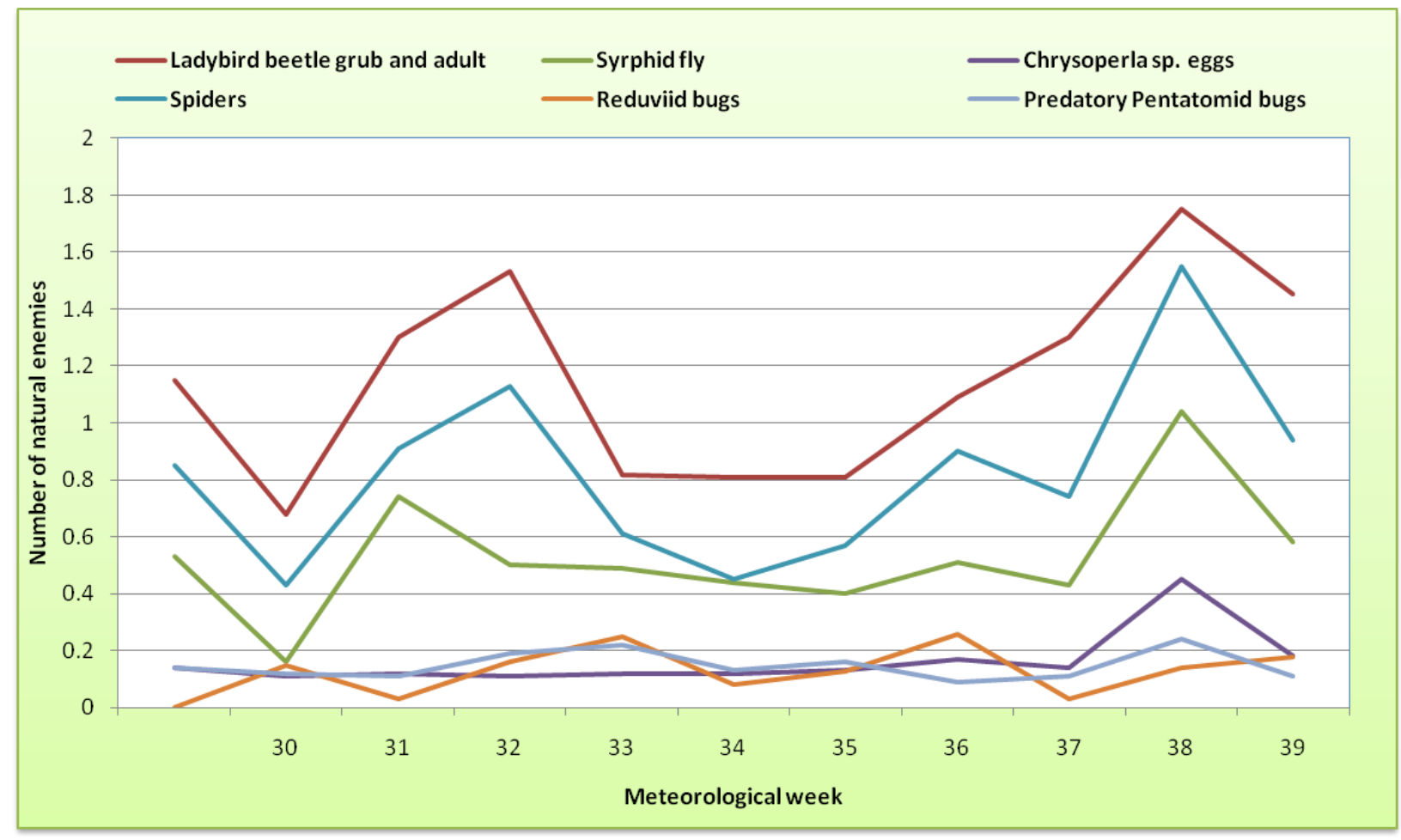

C. septempunctata and $M$. sexmaculatus was dependent upon density and time of appearance of their prey. Spiders were found in large numbers along with less number of other Coccinelidae spp. Choudhury et al., (2012) reported same observation on biocontrol agents of maize of relatively higher population of natural enemies such as spiders, coccinellids, Paederus sp. and Cotesia sp. were observed in the maize ecosystem and these contributed in controlling the pest population. Mixed population of three predominant spider species were prevalent in maize agro ecosystem during the growing seasons of kharif 2014 and kharif 2015. They were the most dominant predators throughout the cropping season. The observations recorded on mixed population/plant revealed that there was no significant difference between abundance of spiders in maize hybrids. The activities of spiders commenced from $30^{\text {th }} \mathrm{SMW}$ and it was continued till $40^{\text {th }}$
SMW in both the growing seasons. The weekly mean population of spiders over two growing seasons reached maximum (1.56/ plant) at $39^{\text {th }}$ and $(1.55 /$ plant $)$ at $39^{\text {th }}$ in maize ecosystem over the years. It was evident from the observations that majority egg laying by C. carnea recorded during $30^{\text {th }}$ and $39^{\text {th }}$ SMW of kharif 2014and again during $38^{\text {th }}$ to $40^{\text {th }}$ SMW of Kharif 2015in maize ecosystem. However, the seasonal weekly average egg numbers over the years varied from 0.07 to 0.43 / plant and 0.04 to $0.47 /$ plant in maize in kharif 2014 and kharif 2015 respectively syrphid maggots reached the peak (1.26. and $0.81 /$ plant in maize at $40^{\text {th }} \mathrm{SMW}$ in the years khari f2014 and kharif 2015 respectively.. The predator remained active up to $40^{\text {th }} \mathrm{SMW}$ i.e., 1st week of October. The mean seasonal population of syrphid maggots ranged from 0.16 to $1.04 /$ plant in maize over the two years. Similarly the eggs of Chilo patellus procured from NBAIR hanged in the maize 
field to see the parasitization in natural condition. It is recorded that over the year $10.4 \%$ eggs parasitized by Trichogramma chilonis present in nature and the larva of maize stem borer parasitized $2.68 \%$ by larval parasitoid Cotesia flavipes.

Predominant lady bird beetle were noticed in early vegetative stage of crop growth. The average seasonal coccinellid population in Kharif 2014 and Kharif 2015 years was in between 1.10 to 1.20 per plant respectively from $30^{\text {th }}$ SMW (19 DAG) to $40^{\text {th }}$ SMW. Number of eggs/ plant laid by the green lacewings, C.carnea recorded during $30^{\text {th }}$ and $39^{\text {th }}$ SMW of Kharif 2014 and again during $38^{\text {th }}$ to $40^{\text {th }}$ SMW of Kharif 2015 in maize ecosystem . However, the seasonal weekly average egg numbers over the years varied from 0.07 to $0.43 /$ plant and 0.04 to $0.47 /$ plant. Swaminathan et al., (2016) reported that the relatively more common aphidophagous predators on maize. Syrphid maggots reached the peak (1.26. and 0.80) / plant in maize at $40^{\text {th }} \mathrm{SMW}$ in the years ranged from 0.68 to $1.75 /$ plant. Pentatomid bug ,Eocanthecona. furcellata was very negligible on maize crop. Reduviid bugs appeared $31^{\text {st }}$ to $40^{\text {th }}$ SMW however in growing seasons the population varied from 0.03 to $0.26 /$ plant. Mixed population of two predominant spider species were prevalent in maize agro ecosystem during the growing seasons The weekly mean population of spiders over two growing seasons reached maximum (1.56/ plant) at $39^{\text {th }}$ and (1.55/ plant) at $39^{\text {th }}$ in maize ecosystem in both the seasons (Fig. 1).

\section{Acknowledgments}

The authors acknowledge the facilities provided by the Officer In-Charge, AICRP on Maize, Odisha University of Agriculture and technology, Bhubaneswar for successful accomplishment of the research.

\section{References}

Aziz R U, Gaherwal S and Sameena 2017. An assessment of the occurrence of natural enemies(predators) against maize stem borer, Chilo partellus, International journal of current advance research 10: 6464-6466

Anonymous, 2014. Annual Report, AICRP on Maize

Chatterji SM., Young WR., Sharma GC. Sayi IV, Chahal BS., Khare B P, Rathore,Y ., Panwar VPS and Siddiqui KH. 1969. Estimation of loss in yield of maize due to insect pests with special reference to borers. Indian Journal of Entomology, 31: 109-15.

Chaudhury N, Saharawat YS, and Kumar P, 2012 IPM: a Technology to Conserve Biological Control Agents in maize. Indian journal of Entomology,74:(4) 348-354

Gomez KA and Gomez AA (1984) Statistical Procedures for Agricultural Research, $2^{\text {nd }}$ edn. Pp. 653

Rana JS 2006, Response of Coccinella septepunctata, Menochilous sexmaculatus (Coleoptera: Coccinelidae to their aphid prey, Lipaphis erysimi (Hemiptera: Aphididae) in Rapeseed mustard. Journal of Entomology 103(1): 81-84

Singh J, Sajjan SS. 1982. Losses in maize yield due to different grades (1 to 9 scale) caused by the maize borer, Chilo partellus (Swinhoe). Ind J Ent. 44:4148.

Swaminathan R, Meena A, Meena BM, 2016. Diversity and predation potential of major aphidophagous predators in maize. Applied ecology and environmental Research 13(4): 10691084. 


\section{How to cite this article:}

Pravasini Behera and Bijoy Kumar Mishra. 2020. Occurrence of Natural Enemies of Maize Stem Borer Chilo partellus (Swinhoe) in Kharif Maize Ecosystem. Int.J.Curr.Microbiol.App.Sci. 9(03): 2409-2417. doi: https://doi.org/10.20546/ijcmas.2020.903.275 